\title{
Fine-scale spatial genetic structure of eight tropical tree species as analysed by RAPDs
}

\author{
BERND DEGEN †* HENRI CARON†, ERIC BANDOU $\uparrow$, LAURENT MAGGIA§, MARIE \\ HÉLÉNE CHEVALLIER $\mid$, ANTOINE LEVEAU $\$$ \& ANTOINE KREMER \\ $\uparrow$ SILVOLAB Guyane, INRA Station de Recherches Forestières, Campus agronomique, BP 709, 97387 Kourou cedex, \\ French Guiana, $\ddagger$ INRA Station de Recherches Forestières, Laboratoire de Génétique des Arbres Forestiers, BP 45, \\ F-33611 Gazinet cedex, France, §CIRAD-Forêt, Campus agronomique, BP 709, 97387 Kourou cedex, French Guiana, \\ and $\uparrow$ CIRAD-Forêt, Campus International de Baillarguet, BP 5035, 34032 Montpellier cedex 1, France
}

\begin{abstract}
The fine-scale spatial genetic structure of eight tropical tree species (Chrysophyllum sanguinolentum, Carapa procera, Dicorynia guianensis, Eperua grandiflora, Moronobea coccinea, Symphonia globulifera, Virola michelii, Vouacapoua americana) was studied in populations that were part of a silvicultural trial in French Guiana. The species analysed have different spatial distribution, sexual system, pollen and seed dispersal agents, flowering phenology and environmental demands. The spatial position of trees and a RAPD data set for each species were combined using a multivariate genetic distance method to estimate spatial genetic structure. A significant spatial genetic structure was found for four of the eight species. In contrast to most observations in temperate forests, where spatial structure is not usually detected at distances greater than $50 \mathrm{~m}$, significant genetic structure was found at distances up to $300 \mathrm{~m}$. The relationships between spatial genetic structure and life history characteristics are discussed.
\end{abstract}

Keywords: genetic distance, permutation test, RAPD, spatial genetic structure, tropical trees.

\section{Introduction}

Information about the spatial genetic structure of tree populations helps to elucidate the forces driving genetic dynamics. It has important implications for the management and conservation of forest genetic resources (Epperson, 1992), as well as for assessment of the expected impacts of forest exploitation and fragmentation (Young \& Merriam, 1994).

Simulation studies have shown that restricted gene flow via pollen and seeds, the spatial distribution pattern of trees and microhabitat selection can all influence the spatial genetic structure of tree populations (Sokal \& Wartenberg, 1983; Epperson, 1990; Epperson \& Li, 1997; Doligez et al., 1998). However, in contrast to theoretical expectations, experimentally observed spatial structure in temperate tree populations is generally weak, in most cases restricted to a scale of 5-80 m, and rarely consistent across loci (Schnabel et al., 1991; Geburek, 1993; Sork et al., 1993; Merzeau et al., 1994; Young \& Merriam, 1994; Shapcott, 1995; Leonardi et al., 1996). Studies of tropical tree populations have

*Correspondence. E-mail: degen.b@kourou.cirad.fr

(c) 2001 The Genetics Society of Great Britain. generally featured trees that occur at low densities in natural populations and for which no strong pattern of spatial structure has been shown (Hamrick et al., 1993; Boshier et al., 1995; Loiselle et al., 1995; Doligez \& Joly, 1997; Caron et al., 1998).

Smouse \& Peakall (1999) explain these weak patterns by a lack of sensitivity in the statistical procedures. They illustrate the advantages of undertaking multilocus analysis, using new polymerase chain reaction (PCR)based genetic markers (e.g. RAPD), in combination with a multivariate approach to autocorrelation analysis. Following the suggestions of Smouse \& Peakall (1999), we applied a genetic distance method to analyse the finescale spatial genetic structure detected by RAPD in a silviculture trial in French Guiana of eight tropical tree species: Carapa procera Aubl. (Meliaceae), Chrysophyllum sanguinolentum L. (Sapotaceae), Dicorynia guianensis Amshoff (Caesalpiniaceae), Eperua grandiflora Aubl. (Caesalpiniaceae), Moronobea coccinea Aubl. (Clusiaceae), Symphonia globulifera L. f. (Clusiaceae), Virola michelii Aubl. (Myristicaceae), Vouacapoua americana Aubl. (Caesalpiniaceae). Owing to low tree densities and the relatively undisturbed history of the study site, an $a$ priori expectation was for a stronger spatial structure in 
the analysed tropical tree species than has been found previously in temperate trees. A further aim of the study was to search for relationships between spatial genetic pattern and different life history characteristics of the species, e.g. pollen and seed dispersal agents and tree density.

\section{Material and methods}

\section{Study site}

All samples for the study were collected at the Paracou experimental trial $\left(5^{\circ} 18^{\prime} \mathrm{N}, 52^{\circ} 53^{\prime} \mathrm{W}\right)$ near Sinnamary in French Guiana. The forest at Paracou is classified as lowland moist forest on ferralitic soil. The mean annual rainfall in this area is $3076 \mathrm{~mm}$ with peaks in April-June and December. There are two dry seasons; a short one in March and a longer one from August to November. The experimental trial consists of 16 natural rainforest plots, 15 are 6.25 ha in size and one covers an area of 25 ha (Fig. 1). Since 1984, all trees with d.b.h. $>10 \mathrm{~cm}$ have been measured by CIRAD-Forêt. The trees have been mapped and, for many, families, genera and species identified. Three silvicultural treatments of different intensities were applied to different plots from 1986 to 1988 , but some were left as unlogged controls. Since then, effective recruitment and strong microenvironmental variation have caused only slight differences inadult densities between logged and unlogged plots. Adetailed description of the experimental trail and

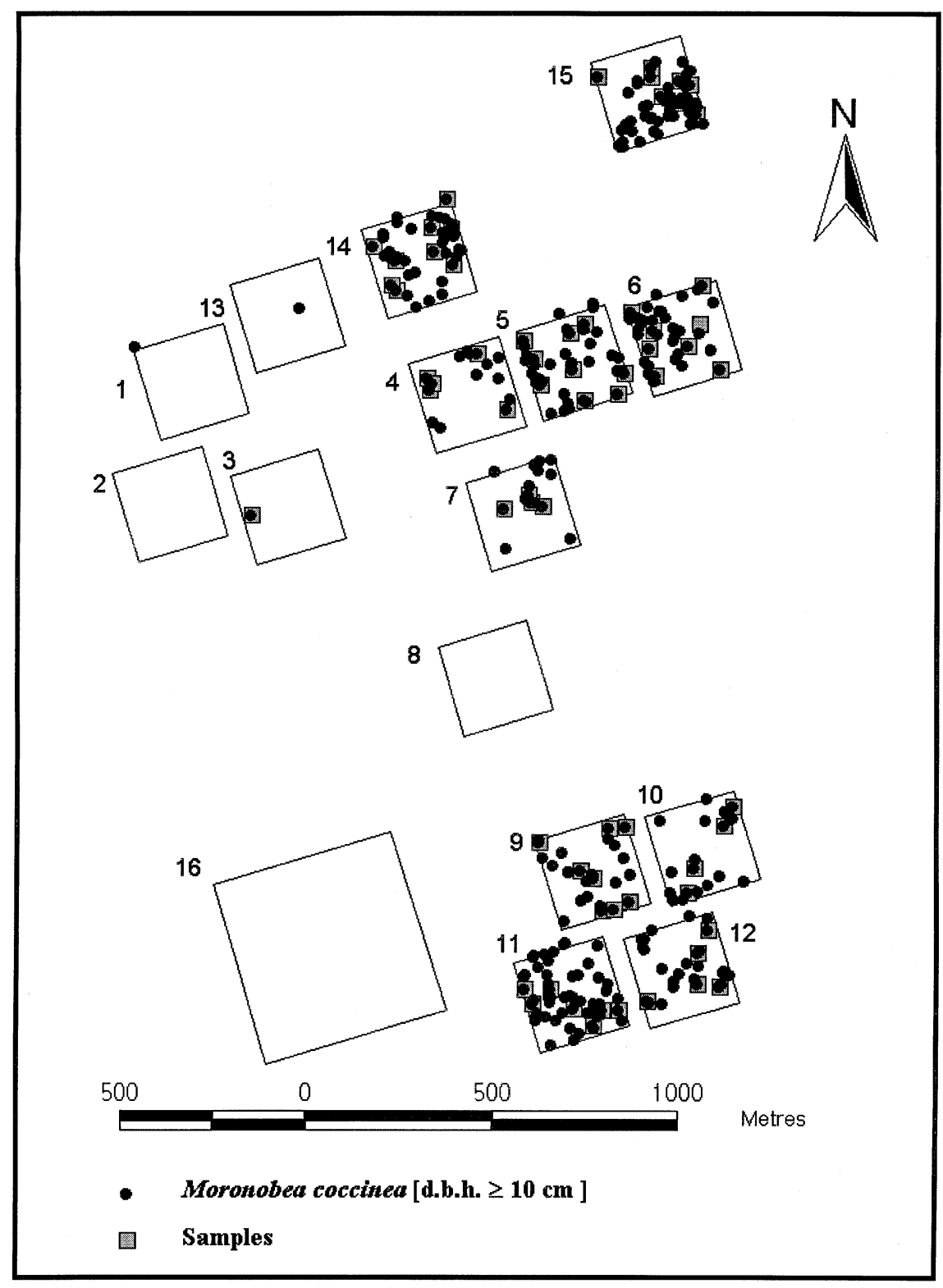

Fig. 1 Position of all trees of Moronobea coccinea [d.b.h. $>10 \mathrm{~cm}$ ] in the Paracou experimental site and distribution of the sampled trees of $M$. coccinea. 
treatments can be found elsewhere (Forget et al., 1999; Schmitt \& Bariteau, 1988).

\section{Species description}

Distribution and tree aggregation. An overview of the characteristics of the eight canopy tree species studied is given in Table 1. Two species have a broad distribution; Carapa procera occurs across the Guyana plateau and also in West and Central Africa, and Symphonia globulifera is distributed across Central and South America and can be found in West Africa. The other six species are more or less restricted to the Guyana plateau and the neighbouring territories of Brazil and Venezuela.

Clark and Evans' index $(R)$ (Ripley, 1981) was used as an indicator of fine-scale spatial distribution of the species within all 16 plots of the study site (Table 1):

$0<R=\frac{\bar{r}_{\text {observed }}}{\bar{r}_{\text {expected }}} ; \bar{r}_{\text {observed }}=\frac{\sum_{i=r}^{N} r_{i}}{N} ; \bar{r}_{\text {expected }}=\frac{1}{2 \cdot \sqrt{\frac{N}{F}}}$

where $r_{\mathrm{i}}$ is the distance of tree $i$ to the next neighbour, $N$ is the total number of trees and $F$ is the size of the plot $\left(\mathrm{m}^{2}\right)$.

Values of index $(R)<1$ indicate a clumped and aggregated distribution, whereas an index value of 1 indicates a random distribution. A regular distribution is described by values $(R)>1$. According to mean $(R)$ values, Dicorynia guianensis, Vouacapoua americana and Eperua grandiflora all have a clumped spatial distribution. The diameter of the aggregates is relatively small for Dicorynia guianensis (50$100 \mathrm{~m}$ ) but relatively large for Vouacapoua americana and Eperuagrandiflora $(100-600 \mathrm{~m})$. The spatialdistribution of the other five species is random within the plots analysed. A detailed study of the spatial distribution of Carapa procera and Vouacapoua americana is given by Forget et al.(1999).

The density of trees (d.b.h. $>10 \mathrm{~cm})$ varied from 11.66 individuals per ha (Symphonia globulifera) to 2.44 individuals per ha (Virola michelii). Some species had large standard deviations for density between plots (Chrysophyllum sanguinolentum, Eperua grandiflora, Moronobea coccinea, Vouacapoua americana). These species tended to occur in large aggregates (up to several $100 \mathrm{~m}$ ) and were often correlated with specific environmental conditions (Forget et al., 1999).

Dispersal, breeding systems, and niche. Two of the species are pollinated by birds: Moronobea coccinea (hummingbirds) and Symphonia globulifera (hummingbirds and perching birds). Chrysophyllum sanguinolentum and Symphonia globulifera are pollinated by bats. Depending on behaviour, both bird and bat pollination can lead to long-distance pollen transport. The other six species are pollinated by insects, which is also a feature of the pollination systems of Chrysophyllum sanguinolentum and Symphonia globulifera. Seed dispersal for Carapa procera, Dicorynia guianensis, Eperua grandiflora, Moronobea coccinea and Vouacapoua americana $(<50 \mathrm{~m})$ is primarily by gravity, and secondarily by rodents (Forget et al., 1999) and is therefore considered restricted. For Chrysophyllum sanguinolentum, seeds are distributed by monkeys and those of Virola michelii are dispersed by birds, monkeys and kinkajous (Potos flavus). Bats have been observed distributing the seeds of Symphonia globulifera. Birds, bats and monkeys are known to disperse seeds up to several hundred metres (Howe, 1990; Julliot, 1994).

Virola michelii is dioecious and the other seven species have a bisexual breeding system (hermaphroditic or monoecious). Carapa procera, Chrysophyllum sanguinolentum, Symphonia globulifera and Virola michelii flower once a year. Dicorynia guianensis has a three-year flowering cycle; after two years of flowering there is a barren year (Caron et al., 1998). The flowering of Moronobea coccinea follows a supra-annual cycle. With an irregular number of years without any flowers, the flowering of Eperua grandiflora and Vouacapoua americana is also irregular and hard to predict. According to shade tolerance and light demands Carapa procera, Symphonia globulifera and Virola michelii are classified as heliophilic species which favour gaps for regeneration (Favrichon, 1994). The other species are hemitolerant or shade-tolerant. Chrysophyllum sanguinolentum and Virola michelii are mostly distributed in dry areas with good water drainage. The other species can tolerate wet soil conditions; Symphonia globulifera often occurs in wet areas at the Paracou site.

\section{Sampling}

The analysed data sets were the result of different projects with variable objectives. Beside the estimation of spatial structure, trees were sampled for gene diversity and mating system estimation. Each of these objectives has its own sampling criteria. An optimal strategy for the analysis of spatial structure would have been to sample trees in each plot proportional to their density. However, the realized sampling strategy did not fit this approach in all cases. A chi-squared test was used to check whether the sampling was proportional to the density of trees in the plots. No significant deviation was found for Chrysophyllum sanguinolentum, Carapa procera and Moronobea coccinea. An example of the location of sampled trees is illustrated for Moronobea coccinea in Fig. 1. For the other species, the sampling was significantly different from a proportional approach. 


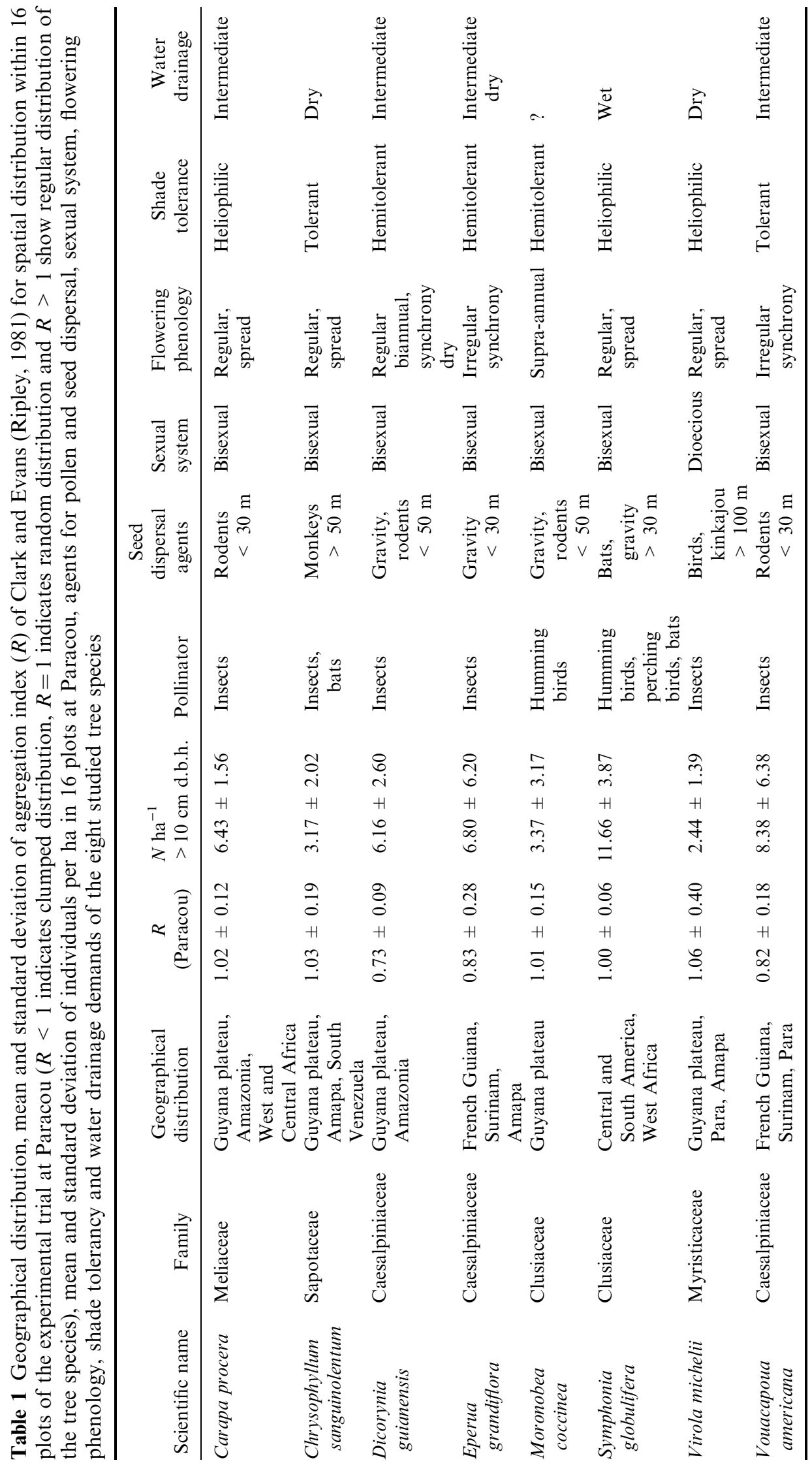

(c) The Genetics Society of Great Britain, Heredity, 87, 497-507. 
An overview of sample size and gene marker system used for each species is given in Table 2 and Table 3.

\section{Genetic analysis}

DNA extraction. Owing to the high density of trees in tropical forest, and the inherent difficulties of reaching the canopy to collect leaves, DNA was extracted from cambial tissue. Leaves were, however, used for a small number of individuals of Dicorynia guianensis. A thin piece of cambium (diameter $2 \mathrm{~cm}$ ) was stamped out of the tree trunk using a leather punch and stored in a mixture of absolute ethanol and $2 \%$ CTAB in the ratio $70: 30 \mathrm{vv} / \mathrm{vv}$ in small tubes. In the field the tubes were kept at ambient temperature and in the laboratory each sample was dried at $50^{\circ} \mathrm{C}$ overnight (E. Bandou, unpubl. method). The extraction method followed a modified protocol of Doyle \& Doyle (1987). DNA extracts were quantified before use by agarose gel electrophoresis against a concentration standard but were sufficient for RAPD analysis in all cases.

RAPD conditions. PCR reactions $(20 \mu \mathrm{L})$ contained 5-10 ng of genomic DNA; $250 \mu \mathrm{M}$ of each of dATP, dCTP, dGTP, and dTTP (Pharmacia); $2.5 \mathrm{~mm}$ of $\mathrm{MgCl}_{2}, 2 \mu \mathrm{M}$ of 10 -mer primer (Operon); and 0.8 unit of Taq DNA polymerase (Gibco BRL). Between 6 and 15 10-mer primers were used for each species (Table 2 ,

Table 2 Number of sampled individuals, number of polymorphic fragments and code of the primers used to analyse the eight species in the Paracou experimental trial. See Table 3 for primer sequences

\begin{tabular}{|c|c|c|c|}
\hline Species & $\begin{array}{l}\text { No. } \\
\text { individuals }\end{array}$ & $\begin{array}{l}\text { No. of } \\
\text { polymorphric } \\
\text { fragments }\end{array}$ & Primers \\
\hline Carapa procera & 65 & 46 & $\begin{array}{l}\text { B-11, E-04, M-05, M-12, N-12, N-15, R-12, W-05, W-12, } \\
\text { Y-04, Y-05, Y15 }\end{array}$ \\
\hline $\begin{array}{l}\text { Chrysophyllum } \\
\text { sanguinolentum }\end{array}$ & 68 & 48 & $\begin{array}{l}\text { E-02, E-05, E0-7, Y-04, Y-06, Y-07, Y-10, Y-13, Y-14, Y-15, } \\
\text { Y-16 }\end{array}$ \\
\hline Dicorynia guianensis & 70 & 52 & Y-09, Y-15, Y-16, Y-17, Y-18, Y-19, Y-20 \\
\hline Eperua grandiflora & 53 & 31 & A-01, J-05, K-09, K-15, K-16, K-17, K-18, K-19, Q-14, U-01 \\
\hline Moronobea coccinea & 68 & 40 & $\begin{array}{l}\text { E-16, E-20, K-09, K-16, K-17, K-19, K-20, Y-04, Y-09, } \\
\text { Y-10, Y-11, Y-17, Y-20 }\end{array}$ \\
\hline Symphonia globulifera & 46 & 39 & $\begin{array}{l}\text { B-12, E-06, H-14, I-13, I-14, I-20, O-04, P-03, P-14, R-09, } \\
\text { S-10, U-19, Y-14, Y-20 }\end{array}$ \\
\hline Virola michelii & 80 & 30 & Y-05, Y-09, Y-10, Y-14, Y-16, Y-18 \\
\hline Vouacapoua americana & 59 & 40 & E-02, E-06, E-19, Y-11, Y-13, Y-14, Y-17 \\
\hline
\end{tabular}

Table 3 Code and sequence of the Operon primers used

\begin{tabular}{llllll}
\hline code & Sequence $5^{\prime}$ to $3^{\prime}$ & code & Sequence $5^{\prime}$ to $3^{\prime}$ & code & Sequence $5^{\prime}$ to $3^{\prime}$ \\
\hline A-01 & CAGGCCCTTC & K-16 & CTCCTGCCAA & W-05 & GGCGGATAAG \\
B-11 & GTAGACCCGT & K-17 & GAGCGTCGAA & W-12 & TGGGCAGAAG \\
B-12 & CCTTGACGCA & K-18 & CCTAGTCGAG & Y-04 & GGCTCCAATG \\
E-02 & GGTGCGGGAA & K-19 & CACAGGCGGA & Y-05 & GGCTGCGACA \\
E-04 & GTGACATGCC & K-20 & GTGTCGCGAG & Y-06 & AAGGCTCACC \\
E-05 & TCAGGCAGGT & M-05 & GGGAACGTGT & Y-07 & AGAGCCGTCA \\
E-06 & AAGACCCCTC & M-12 & GGGACGTTGG & Y-09 & AGCAGCGCAC \\
E-07 & AGATGCAGCC & N-12 & CACAGACACC & Y-10 & CAAACGTGGG \\
E-16 & GGTGACTGTG & N-15 & CAGCGACTGT & Y-11 & AGACGATGGG \\
E-19 & ACGGCGTATG & O-04 & AAGTCCGCTC & Y-13 & GGGTCTCGGT \\
E-20 & AACGGTGACC & P-03 & CTGATACGCC & Y-14 & GGTCGATCTG \\
H-14 & ACCAGGTTGG & P-14 & CCAGCCGAAC & Y-15 & AGTCGCCCTT \\
I-13 & CTGGGGCTGA & Q-14 & GGACGCTTCA & Y-16 & GGGCCAATGT \\
I-14 & TGACGGCGGT & R-09 & TGAGCACGAG & Y-17 & GACGTGGTGA \\
I-20 & TCATCCGAGG & R-12 & ACAGGTGCGT & Y-18 & GTGGAGTCAG \\
J-05 & CTCCATGGGG & S-10 & ACCGTTCCAG & Y-19 & TGAGGGTCCC \\
K-09 & CCCTACCGAC & U-01 & ACGGACGTCA & Y-20 & AGCCGTGGAA \\
K-15 & CTCCTGCCAA & U-19 & GTCAGTGCGG & & \\
\hline
\end{tabular}

(C) The Genetics Society of Great Britain, Heredity, 87, 497-507. 
Table 3). A thermal cycler (GeneAmp PCR system 9600, Perkin Elmer) was programmed for one preamplification step of $1 \mathrm{~min}$ at $94^{\circ} \mathrm{C}$, followed by 20 cycles, with a denaturation step of $30 \mathrm{~s}$ at $94^{\circ} \mathrm{C}$, annealing step of $50 \mathrm{~s}$, progressively decreasing by $1 \mathrm{~s}$ per cycle, at $37^{\circ} \mathrm{C}$, and extension step of $1 \mathrm{~min}$ at $72^{\circ} \mathrm{C}$. Finally 30 more cycles, with a denaturation step of $30 \mathrm{~s}$ at $93^{\circ} \mathrm{C}$, annealing step of $30 \mathrm{~s}$ at $37^{\circ} \mathrm{C}$, and extension step of $1 \mathrm{~min}$ at $72^{\circ} \mathrm{C}$, were used. The final 15 extension steps were progressively extended by $5 \mathrm{~s}$ per cycle and the last cycle was followed by $2 \mathrm{~min}$ at $72^{\circ} \mathrm{C}$. After amplification, $5 \mu \mathrm{L}$ of the samples was loaded and fragments separated by electrophoresis in $1.8 \%$ agarose gels using a $0.5 \times$ TBE running buffer.

\section{Data analysis}

The RAPD data for each individual were recorded as a matrix where a value of 1 indicated fragment presence and 0 coded fragment absence. Only those fragments that were amplified reproducibly and facilitated a clear band identification were used in the study. As suggested by Smouse \& Peakall (1999), a genetic distance method was used to analyse the spatial genetic structure of multilocus RAPD profiles. Using the program SGS (Degen, 2000), spatial genetic structure was analysed as mean genetic distances $\left(D_{k}\right)$ between all pairs of trees belonging to a given spatial distance class $(k)$. In the case of spatial genetic structure, the genetic distance, $D_{k}$, increased with spatial distances (Degen \& Scholz, 1998; Vendramin et al., 1999).

The genetic dissimilarity $\left(D_{i j}\right)$ between the binary profile of two individuals, $i$ and $j$, was computed using Tanimoto's distance (Deichsel \& Trampisch, 1985):

$0 \leq D_{i j}=1 \quad \frac{w_{i j}}{w_{i j}+y_{i}+y_{j}} \leq 1$,

where $w_{i j}$ represents the number of fragments shared between individuals $i$ and $j$, the number of fragments which were only recorded in either individual $i$ or $j$ is indicated by $y_{i}$ and $y_{j}$, respectively. For random spatial structure, the probability that two genotypes are selected for a pairwise distance calculation is the same for all distance classes, it only depends on the frequency of genotypes. Hence, the overall mean of genetic distances $\left(D_{\mathrm{r}}\right)$ between all trees serves as a reference for random spatial structure. Distances below this reference indicate a spatial structure where genotypes are more similar than expected for a random distribution and values above this reference indicate greater genetic differences than expected for a random spatial genetic structure. The plot of spatial distance classes against mean genetic distance $\left(D_{k}\right)$ is called a distogram.

In a pre-analysis of the data it was shown that the method of calculating mean genetic distances is more sensitive to detecting spatial genetic structures than using coefficients of correlation between genetic and spatial distances (Smouse \& Peakall, 1999).

Test. A permutation procedure using Monte Carlo simulations was applied to test significant deviation from random spatial distribution of the mean Tanimoto distance $D_{k}$ (Manly, 1997). Each permutation consisted of a random redistribution of the RAPD profiles over the spatial coordinates of the sampled trees. For each of the spatial distance classes $h_{k}$, observed values were compared with the distribution obtained after 5000 permutations. A $99 \%$ confidence interval for the parameters was constructed as the interval from the 25th to the 4975th ordered permutation estimates (Streiff et al., 1998). Each distogram has, according to the number of spatial distance classes, several $D_{k}$-values that have to be tested. In order to control the overall probability of mistakenly declaring $D_{k}$-values as significant, the significance level used is set at $5 \% / \mathrm{m}$, where $m$ is the number of values tested. The Bonferroni inequality then ensures that the probability of erroneously declaring any difference significant is 0.05 or less (Manly, 1997; p. 108). With eight distance classes, the significance level is $5 / 8=0.62 \%$. To guarantee this level, we used the $99 \%$ confidence interval with $0.5 \%$ of the $D_{k}$-values outside the interval at each side of the distribution.

\section{Results}

For all eight species, the mean genetic distances were calculated for eight different spatial distance classes of $150 \mathrm{~m}$ each from 0 to $1200 \mathrm{~m}$. The size of $150 \mathrm{~m}$ for each spatial distance class was chosen so that in all cases at least 30 pairs of trees belonged to each class. This critical limit was suggested for statistical reasons by Wartenberg (Doligez \& Joly, 1997). All distograms and the $99 \%$ confidence intervals of the permutation tests are given in Fig. 2. For six out of eight species, the mean genetic distance, $D_{k}$, of the first two distance classes is below that of the reference value.

The distograms demonstrate that significant $D_{k}$-values are found for the first $150 \mathrm{~m}$ for Carapa procera, Virola michelii and Vouacapoua americana (Fig. 2). Moronobea coccinea has significant values for the first two distance classes $(<300 \mathrm{~m})$. The remaining species displayed no significant values for any distance class, $D_{k}$-values of Chrysophyllum sanguinolentum, 


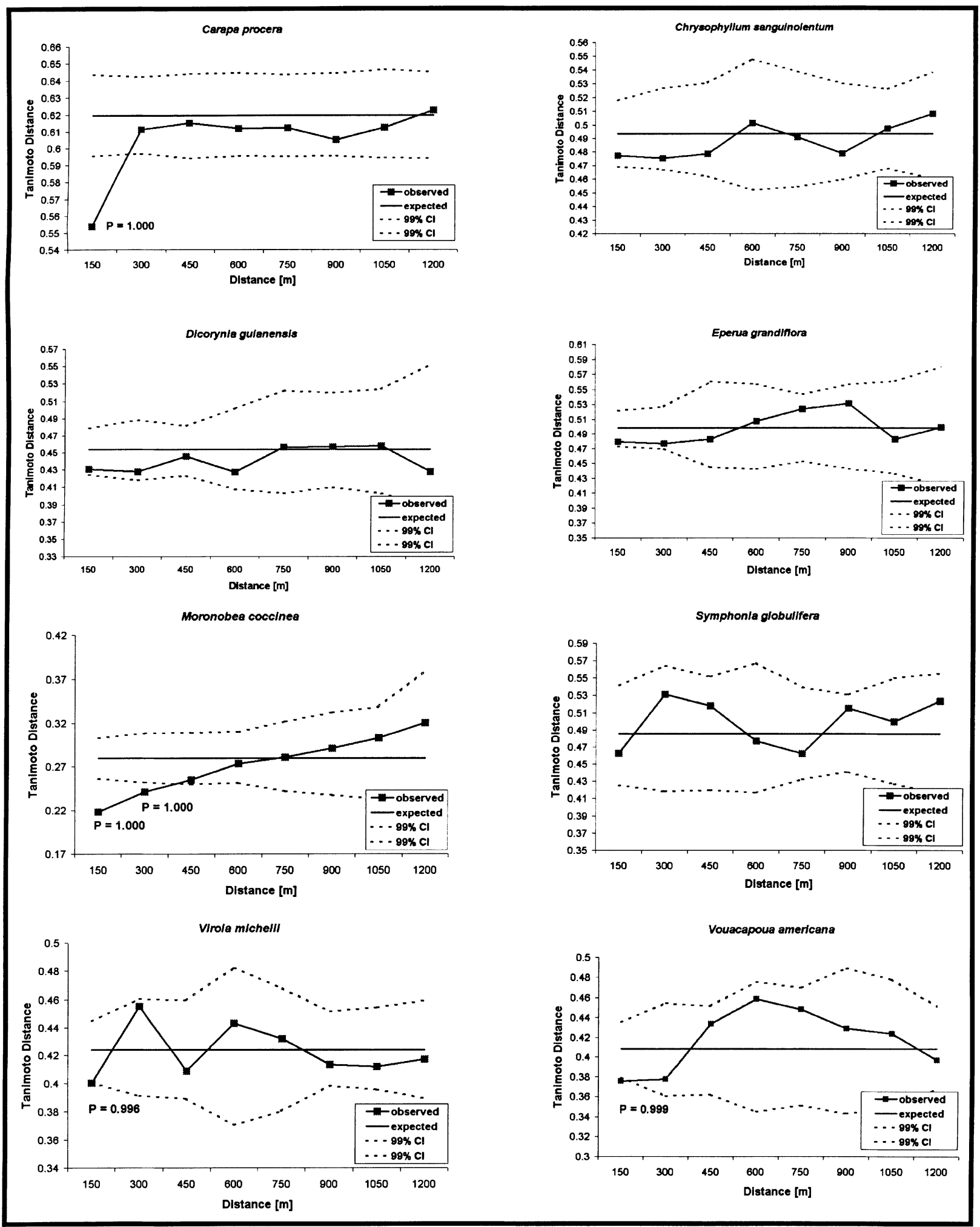

Fig. 2 RAPD distogram of Carapa procera, Chrysophyllum sanguinolentum, Dicorynia guianensis, Eperua grandiflora, Moronobea coccinea, Symphonia globulifera, Virola michelii and Vouacapoua americana, $P$, probability for $D_{k}$ values to be greater than the observed values estimated with 5000 permutations.

(C) The Genetics Society of Great Britain, Heredity, 87, 497-507. 
Dicorynia guianensis and Eperua grandiflora are close to the limit of confidence.

We also tested whether calculating distograms for single RAPD fragments was more or less sensitive than detecting spatial genetic structure using a multilocus approach. By using the same procedure that was applied to multilocus calculation for Moronobea coccinea and Carapa procera, distograms were computed using each RAPD fragment for eight spatial distance classes (each of $150 \mathrm{~m}$ in size). Again the significance of each genetic distance $D_{k}$ was tested for 5000 permutations. The tests for single RAPD fragments for Monorobea coccinea revealed that $14 \%$ of all $D_{k}$-values were significant (6.24\% for Carapa procera), whereas when using the multilocus approach, $25 \%$ of values were significant (12.5\% for Carapa procera). Thus, the empirical results presented herein are consistent with the theoretically expected advantage of the multilocus approach (Smouse \& Peakall, 1999).

\section{Discussion}

\section{Application of RAPDs for analysis of spatial genetic structure}

RAPDs are sometimes criticized owing to reproducibility problems (Ford-Lloyd \& Painting, 1996) and their sensitivity to small alterations in PCR conditions. Such nonsystematic bias may mask spatial genetic structure, but it is highly unlikely that such variation could generate spatial structure as an artefact. Another issue in this context is the mode of inheritance of RAPDs. The general interpretation is that RAPDs are biparentally inherited dominant markers. According to the relationship between the genome sizes of the nuclear and cytoplasmic DNA there should only be a small proportion of fragments that are located within organelles, and which will be inherited uniparentally. Olmstead \& Palmer (1994) indicate that 'the typical chloroplast genome size in angiosperms ranges from 135 to $160 \mathrm{kbp} . . .2$. Information on the nuclear genome comes from Arumuganathan \& Earle (1991), who reported on the nuclear DNA content of some important plant species. For angiosperm trees, they listed a range of values from $396 \mathrm{Mbp}$ (Citrus) to $796 \mathrm{Mbp}$ (Malus), with some species exhibiting great intraspecific variation, e.g. Prunus, 300-800 Mbp. Thus, the relationship between the size of organelle and nuclear genomes of trees is in the range of 1:300-1:5000. This means that if RAPDs are distributed randomly over the whole genome, the proportion of uniparentally inherited fragments should be low. Lu et al. (1995) analysed the inheritance of RAPD fragments for Pinus sylvestris. In their study, segregating fragments were either present or absent confirming the dominant character of RAPDs. None of the detected fragments appeared to originate from uniparentally inherited cytoplasmic DNA. In contrast to these findings, Aagaard et al. (1998) screened the inheritance of 237 RAPD fragments in Douglas fir and found that $19 \%$ of the fragments originated in the mitochondrial and chloroplast genome. Hence, in the absence of inheritance data for the RAPD fragments in the present study, we interpret them as a mixture of dominant biparentally and maternally inherited markers. The fragments are affected by both the pollen flow and the seed flow.

\section{Spatial structure and seed dispersal}

The seeds of Carapa procera, Dicorynia guianensis, Eperua grandiflora, Moronobea coccinea and Vouacapoua americana are dispersed primarily by gravity but are also distributed by rodents (secondary dispersal), not more than $50 \mathrm{~m}$ away from the mother tree (Forget, 1992; Forget et al., 1999). With the exception of C. procera, trees (d.b.h. $>10 \mathrm{~cm}$ ) of these species had an aggregated spatial distribution in the Paracou experimental site (see Clark and Evans' Index $(R)$ in Table 1). These aggregates could also be caused by microenvironmental differences favouring different species in different patches (Forget et al., 1999). Three of five species in this group displayed a significant spatial genetic structure for the first distance class $(<150 \mathrm{~m})$.

The seeds of Chrysophyllum sanguinolentum, Symphonia globulifera and Virola michelii are distributed primarily by animals and hence would be expected to be dispersed over large distances. Symphonia globulifera and Chrysophyllum sanguinolentum showed no spatial genetic structure, in contrast to Virola michelii. Hence, no simple causal link was found between seed dispersal and spatial genetic structure (short seed dispersal, strong genetic structure; long seed dispersal, weak genetic structure).

The fine-scale spatial structure for maternally inherited cpDNA markers have been studied for Dicorynia guianensis in one plot in Paracou (Caron et al., 2000), where significant autocorrelation was detected for adult trees up to $130 \mathrm{~m}$; this significant structure was interpreted to be primarily the result of limited seed dispersal.

Ecological investigations of frugivory and seed dispersal of the red howler monkeys in French Guiana, have shown that the monkeys regularly use a limited number of sleeping sites and exhibit a very long digestive time. Concentrations of faeces which contain large numbers of ingested seeds, occur under sleeping trees (Julliot, 1994). As a consequence of this behaviour, long-distance seed dispersal by monkeys does not 
necessary imply a random distribution of seeds and may produce aggregates of saplings which consist of single tree progenies. For some tropical tree species the effect of restricted seed dispersal may be overshadowed by high mortality of seedlings in the neighbourhood of parent tree (Harms et al., 2000). This phenomenon has been studied in the bird-dispersed Virola surinamensis in Panama (Howe, 1990). As part of the investigation, 54\% of seeds were scattered randomly in the forest, while $46 \%$ were dropped under the parent trees. Owing to the high density of seed predators and pathogens, seed and seedling mortality under the parent trees exceeded $99.99 \%$. Only seeds dispersed away from the parent tree had an appreciable chance of survival. This tendency could help explain why tree species with restricted seed dispersal strategies exhibit no or very weak spatial genetic autocorrelation in the most proximate distance classes.

Using allozymes, Hamrick et al. (1993) studied the influence of seed dispersal mechanism on the genetic structure of four tropical tree species at Barro Colorado Island in Panama. They found that Platypodium elegans, a low-density, wind-dispersed species, displayed the strongest spatial structure, while Swartzia simplex, a high-density, bird-dispersed species, had only weak spatial structure. They also compared the spatial genetic structure at different life history stages. For two species, Platypodium elegans and Alseis blackiana, spatial genetic structure present in the seedling cohort disappeared in later life history stages.

Significant spatial structure was shown in a distance class of size $<150 \mathrm{~m}$ for Carapa procera and Vouacapoua americana and $<300 \mathrm{~m}$ for Moronobea coccinea (Fig. 2). Because the dispersal of seeds is expected to be below this range, this can be seen either as spatial structure developed over a long period of time in a natural forest or as the combined effect of seed and pollen dispersal.

As many of the species were noted as having seed dispersal distance $<50 \mathrm{~m}$, it is possible that greater spatial structure may have been detected if it had been possible to further partition the $150 \mathrm{~m}$ classes. This was restricted by the sample sizes.

\section{Spatial structure and pollen dispersal}

Chrysophyllum sanguinolentum (bats and insects), Moronobea coccinea (hummingbirds) and Symphonia globulifera (hummingbirds, perching birds and bats) are ranked as species with high pollen dispersal capability. The pollen of the other species studied here are distributed by insects and dispersal is therefore expected to be more limited. A clear relationship between spatial genetic structure and this life history trait was, however, not evident. For example, Symphonia globulifera and
Chrysophyllum sanguinolentum, which are bat and/or bird pollinated, showed no genetic structure in the distograms (Fig. 2), whereas genetic structure was shown by Moronobea coccinea, a hummingbird pollinated species. One potential problem is that there are large variations in the potential flight distances of different insect pollinators (Roubik, 1989). Hence, a simple classification such as insect pollinated and noninsect pollinated species may be insufficient.

\section{Spatial structure and density of individuals}

The occurrence of trees of Symphonia globulifera at relatively high density $\left(11.66\right.$ trees $\left.\mathrm{ha}^{-1}\right)$ may explain the absence of any spatial genetic structure. In areas with high densities of individuals, overlapping seed shadows may produce a mixture of different single tree progenies. In such cases only weak spatial structure is expected (Hamrick et al., 1993).

\section{Spatial structure and sampling strategy}

For all eight species, samples were taken from individuals located in different plots of the experimental site at Paracou. For Chrysophyllum sanguinolentum, Carapa procera and Moronobea coccinea the sampling was proportional to the density in each plot. For the other species, some plots were over-represented. Because the permutation test made a random redistribution of the RAPD profiles over the existing spatial co-ordinates of the trees, the chance that significant spatial structure could be detected as a result of the location of sampled trees is effectively eliminated.

The total sample is an amalgamation of data from different trial plots where intensity of sampling is high, but between which there has been no sampling (e.g. Fig. 1). This sampling design was determined during the original design of the experimental Paracou trial (Schmitt \& Bariteau, 1988), which aimed primarily to investigate ecological and species distribution questions. How suitable then is this sampling strategy to detect 'real' spatial genetic structure within populations? The construction of distograms is based on mean genetic distances, $D_{k}$, computed for pairs of trees belonging to the same spatial distance classes. The precision of the estimated $D_{k}$ value increases with increasing numbers of trees belonging to that distance class. Generally, our groupwise sampling design led to an over-representation of pairs of trees separated by short spatial distances and an under-representation of pairs of trees separated by longer distances. Hence, it may be that the spatial genetic structure present at the larger scale is not detected by the imposed sampling design but it is unlikely that the significant genetic structures detected in

(C) The Genetics Society of Great Britain, Heredity, 87, 497-507. 
this study within the proximate distance classes are an artefact.

\section{Advantage of the new approach}

The application of a multilocus approach using PCRbased genetic markers in combination with the genetic distance calculation method used have been shown to be more sensitive and efficient in detecting spatial genetic structure than former approaches using allozyme data and single allele statistics such as Moran's Index (Smouse \& Peakall, 1999). The results of the present study fully support this observation. For four of the eight species studied here, significant spatial structure was revealed using RAPD analysis (Fig. 2). In a former study of spatial genetic structure of Carapa procera at the same experimental site, no spatial structure was found based on allozyme variation (Doligez \& Joly, 1997). In contrast, the present RAPD study detected significant spatial structure up to $300 \mathrm{~m}$ for this species. Differences in sample sizes cannot explain these contrasting results, as for allozymes more samples were analysed.

\section{Acknowledgement}

This study was financially supported by two European Union projects (program INCO: TS3*CT94-0316, STD3 project) and two French grants: one from BRG (Bureau des Resources Génétiques) and a grant from the French Ministry of Environment (SOFT-project 1995). We are thankful to Cirad-Forêt for giving us access to the Paracou experimental site and for providing data. We wish to thank Catherine Julliot and Damien Bonal for helpful information on species ecology and Andrew Lowe, Cyril Dutech and two anonymous reviewers for useful comments on the manuscript.

\section{References}

AAGAARD, J. E., KRUTOVSKII, K. V. AND STRAUSS, S. H. 1998. RAPD markers of mitochondrial origin exhibit lower population diversity and higher differentiation than RAPDs of nuclear origin in Douglas fir. Mol. Ecol., 7, 801-812.

ARUMUganAthan, K. AND EARLE, E. D. 1991. Nuclear DNA content of some important plant species. Plant Mol. Biol. Report, 9, 208-219.

BoshiER, D. H., CHASE, M. R. AND BAWA, K. S. 1995. Population genetics of Cordia alliodora (Boraginaceae), a neotropical tree. 3. Gene flow, neighborhood and population substructure. Am. J. Bot., 82, 484-490.

CARon, H., Dumas, S., marque, G., Messier, C., Bandou, E., PETIT, R. J. ET AL. 2000. Spatial and temporal distribution of chloroplast DNA polymorphism in a tropical tree species. Mol. Ecol., 9, 1089-1098.
CARON, H., DUTECH, C. AND BANDOU, E. 1998. Variations spatiotemporelles du régime de reproduction de Dicorynia guianensis Amshoff (Caesalpiniaceae) en forêt guyanaise. Genet. Sel. Evol., 30, 153-166.

DEGEN, B. 2000. SGS: Spatial Genetic Software. Computer Program and User's Manual. http://kourou.cirad.fr/genetique/software.html.

DEGEN, B. AND SCHOLZ, F. 1998. Spatial genetic differentiation among populations of European beech (Fagus sylvatica L.) in Western Germany as identified by geostatistical analysis. Forest Gen., 5, 191-199.

DEICHSEL, G. AND TRAMPISCH, H. J. 1985. Clusteranalyse und Diskriminanzanalysel. Gustav Fischer, Stuttgart.

DOLIGEZ, A. AND JOLY, H. I. 1997. Genetic diversity and spatial structure within a natural stand of a tropical forest tree species, Carapa procera (Meliaceae), in French Guiana. Heredity, 79, 72-82.

DOLIGEZ, A., BARIL, C. AND JOLY, H. I. 1998. Fine-scale spatial genetic structure with non-uniform distribution of individuals. Genetics, 148, 905-920.

DOYLE, J. J. AND DOYLE, J. L. 1987. A rapid DNA isolation procedure for small quantities of fresh leaf tissue. Phytochem. Bull., 19, 11-15.

EPPERSON, B. K. 1990. Spatial autocorrelation of genotypes under directional selection. Genetics, 124, 757-771.

EPPERSON, B. K. 1992. Spatial structure of genetic variation within populations of forest trees. New Forests, 6, 257-278.

EPPERSON, B. K. AND LI, T. Q. 1997. Gene dispersal and spatial genetic structure. Evolution, 51, 672-681.

FAVRICHON, V. 1994. Classification des espèces arborées en groupes fonctionnels en vue de la réalisation d'un modèle de dynamique de peuplements en forêt guyanaise. Terre et Vie, 49, 379-403.

FORD-LlOYD, B. AND PAINTING, K. 1996. Measuring Genetic Variation Using Molecular Markers. IPGRI, Rome.

FORGET, P. M. 1992. Regeneration ecology of Eperua grandiflora (Caesalpiniaceae), a large-seeded tree in French Guiana. Biotropica, 24, 146-156.

FORGET, P. M., MERCIER, F. AND COLlinet, F. 1999. Spatial patterns of two rodent-dispersed rainforest trees, Carapa procera (Meliaceae) and Vouacapoua americana (Caesalpiniaceae) at Paracou, French Guiana. J. Trop. Ecol., 15, 301-313.

GEBUREK, T. 1993. Are genes randomly distributed over space in mature populations of Sugar Maple (Acer saccharum Marsh.) Ann. Bot., 71, 217-222.

HAMRICK, J. L., MURAWSKI, D. A. AND NASON, J. D. 1993. The influence of seed dispersal mechanisms on the genetic structure of tropical tree populations. Vegetatio, 107, 281-297.

HARMS, K. E., WRIGHT, S. J., CALDERON, O., HERNANDEZ, A. AND HERRE, E. A. 2000. Pervasive density-dependent recruitment enhances seedling diversity in a tropical forest. Nature, 404, 493-495.

HOWE, H. F. 1990. Seed dispersal by birds and mammals: implications for seedling demography. In: Bawa, K. S. and Hadely, M. (eds) Reproductive Ecology of Tropical Forest Plants, pp. 191-218. Parthenon Publishers Group/UNES$\mathrm{CO}$, Paris. 
JULLIOT, C. 1994. Frugivory and seed dispersal by red howler monkeys: Evolutionary aspect. Rev. Ecol. - Terre et Vie, 49, 331-341.

LEONARDI, S., RADDI, S. AND BORGHETTI, M. 1996. Spatial autocorrelation of allozyme traits in a Norway spruce (Picea abies) population. Can. J. Forest Res., 26, 63-71.

LOISElle, B. A., SORK, V. L., NASON, J. AND GRAHAM, C. 1995. Spatial genetic structure of a tropical understorey shrub, Psychotria officinalis (Rubiaceae). Am. J. Bot., 82, 1420-1425.

LU, M. Z., SZMIDT, A. E. AND WANG, X. R. 1995. Inheritance of RAPD fragments in haploid and diploid tissues of Pinus sylvestris L. Heredity, 74, 582-589.

MANLY, B. F. J. 1997. Randomization, Bootstrap and Monte Carlo Methods in Biology. Chapman \& Hall, London.

MERZEAU, D., COMPS, B., THIEBAUT, B., CUGUEN, J. AND LETOUZEY, J. 1994. Genetic structure of natural stands of Fagus sylvatica L. (Beech). Heredity, 72, 269-277.

Olmstead, R. G. AND PALMER, J. D. 1994. Chloroplast DNA sytematics: a review of methods and DNA analysis. Am. J. Bot., 81, 1205-1224.

RIPLEY, B. D. 1981. Spatial Statistics. Probability and Mathematical Statistics Series. Wiley, New York.

RoubiK, D. W. 1989. Ecology and Natural History of Tropical Bees. Cambridge University Press, Cambridge.

SCHMITT, L. AND BARITEAU, M. 1988. Gestion de l'ecosysteme forestier guyanais: Etude de la croissance et de la regeneration naturelle: Dispositif de Paracou. Bois Foret. Trop., 220, 3-24.

SCHNABEL, A., LAUSHMAN, R. H. AND HAMRICK, J. L. 1991. Comparative genetic structure of two co-occurring tree species, Maclura pomifera (Moraceae) and Gleditsia triacanthos (Leguminosae). Heredity, 67, 357-364.

SHAPCOTT, A. 1995. The spatial genetic structure in natural populations of the Australian temperate rainforest tree Atherosperma moschatum (Labill.) (Monimiaceae). Heredity, 74, 28-38.

SMOUSE, P. E. AND PEAKALl, R. 1999. Spatial autocorrelation analysis of individual multiallele and multilocus genetic structure. Heredity, 82, 561-573.

SOKAL, R. R. AND WARTENBERG, D. E. 1983. A test of spatial autocorrelation analysis using an isolation-by-distance model. Genetics, 105, 219-237.

SORK, V. L., HUANG, S. AND WIENER, E. 1993. Macrogeographic and fine-scale genetic structure in a North American oak species, Quercus rubra L. Ann. Sci. For., 50, 261-270.

STREIFF, R., LABBE, T., BACILIERI, R., STEINKELLNER, H., GLOSSL, J. AND KREMER, A. 1998. Within-population genetic structure in Quercus robur L. \& Quercus petraea (Matt.) Liebl. assessed with isozymes and microsatellites. Mol. Ecol., 7, 317-328.

VENDRAMIN, G. G., DEGEN, B., PETIT, R. J., ANZIDEI, M., MADAGHIELE, A. AND ZIEGENHAGEN, B. 1999. High level of variation at Abies alba chloroplast microsatellite loci in Europe. Mol. Ecol., 8, 1117-1126.

YOUNG, A. G. AND MERRIAM, H. G. 1994. Effects of forest fragmentation on the spatial genetic structure of Acer saccharum Marsh. (sugar maple) populations. Heredity, 72, 201-208. 